\title{
THE ROLE PLAYED BY EXOTIC PLANTS IN URBAN ECOSYSTEMS: COMMENTS ON SPENNEMANN (2019)
}

\author{
Fabio Angeoletto ${ }^{1, *}$, Leandro Bernardo Leite ${ }^{1}$, Taise Ernestina Prestes Nogueira Duarte ${ }^{1}$, \\ JUCIANE MARIA JOHANN ${ }^{1}$ AND ISABELA NEGRI ${ }^{1}$ \\ 'Programa de Pós-Graduação em Geografia da Universidade Federal de Mato Grosso, Rodovia \\ Rondonópolis/Guiratinga, S/N, Km 06, Rondonópolis, MT 78735-901, Brasil
}

\begin{abstract}
.
The article written by Dirk HR Spennemann, and published in the European Journal of Ecology, addresses the role played by a palm tree species native to the Canary Islands as food source for several frugivore species found in Australian cities. This palm tree bears fruit throughout the year; therefore, it is a reliable food source in winter and helps increasing wildlife support. Spennemann avoids the native versus exotic dogmatic simplism; instead, he assesses the palm tree species based on its positive environmental impact.
\end{abstract}

Key words: native versus exotic; urban ecology; urban ecosystems; urban biodiversity; urban planning; ornamental plants; Phoenix canariensis; birds; urban fauna; urban flora.

The article entitled The contribution of the $\mathrm{Ca}$ nary Island date palm (Phoenix canariensis) to the winter diet of frugivores in novel ecosystems presents results of an interesting study about the consumption of Phoenix canariensis fruits by frugivores living in urban ecosystems (Spennemann, 2019).

Spennemann analyzes the role played by palm trees grown in cities for ornamental purposes as food source for the wildlife living in urban ecosystems, by taking into consideration that many animal species have adapted to eat plants introduced in cities. Based on observational, metric and biochemical data, Spennemann concludes that Phoenix canariensis fruits are available to the local fauna throughout the year, mainly to birds; therefore, these palm trees are stable and important food supply to different bird species found in Australian cities, even in winter.

Cities are heterotrophic ecosystems influenced by environmental factors, as well as by social, economic, political, urban and cultural dynamics (Angeoletto et al., 2019a; Rumble et al., 2019). Therefore, it is not possible to accurately understand the ecology of cities without analyzing its human factors and their influence on urban fauna and flora (Angeoletto et al., 2019b; Iwaniec et al., 2020).

Spennemann makes a detailed description about the dispersion of Phoenix canariensis specimens from their land of origin (the Canary Islands) to countries such as Australia, Italy and France. Mor- phological features of this palm tree species, such as its exuberant ornamental crown, as well as cultural factors (the status provided by this plant turned it into a common choice for wealthy families' gardens) are listed by him to explain its popularity. Species Phoenix canariensis is found in many cities of subtropical and tropical countries such as Brazil (Andreatta et al., 2011). One eloquent article cited by Spenneman reported the planting of 600,000 palm trees in the province of Alicante (Spain) in a single year - one palm tree for every three residents living in the province (Hernández et al., 2014).

Spenneman properly points out the concerning scarcity of studies focused on measuring the nutritional features of fruits that are not consumed by humans on a regular basis, and that is precisely his article's greatest merit. He accurately describes the nutritional potential of palm tree fruits. In addition, based on palm trees' abundant annual fruit yield $(5,000$ to 30,000 drupes) and longevity (they can live up to 300 years, and exceptionally, 400 years, with proper handling), he states that drupe availability as food source for frugivores throughout most of the year is unquestionable, since these fruits provide high protein, sugar and energy contents. In the aforementioned article, as well as in the two more papers (Spennemann, 2018; Spennemann, 2019b), Spennemann observed that the following bird species fed on Phoenix canariensis drupes: Strepera graculina, Pte- 
ropus poliocephalus, Sturnus vulgaris, Anthochaera carunculata, Turdus merula, Eudynamys orientalis and Corvus coronoides.

Despite the solid evidence that clearly suggests the key role played by palm trees in supporting several wild bird species living in Australian cities, Spennemann is cautious in his conclusions and suggests that further studies on the topic should be conducted.

According to him:

Further studies of exotic and native vectors are needed, especially stratified studies that examine the diet of vectors that inhabit the various ecological niches along the landscape gradient urban $\longleftrightarrow$ sub-urban $\longleftrightarrow$ peri-urban agricultural $\longleftrightarrow$ remnant bushland. There is also a need to more systematically study the provisioning services of Canary Island date palm in diverse ecosystems such as southern Europe, southern China, and the southern states of the USA, and to assess whether species have become reliant on the provisioning of drupes as a 'staple' and backup food source.

Spennemann's article is successful in showing the positive role played by exotic plant species in supporting urban biodiversity. He avoids the simplistic dichotomy "native plants species are desirable versus exotic plant species are undesirable". Such simplism is obviously an obstacle to ones' understanding about the complexity inherent to cities and to biological diversity management processes taking place in them. Scientists and managers must abandon the native-exotic simplism and adopt a dynamic approach to biodiversity conservation, mainly in urban ecosystems (Davis et al., 2011). Macaws (Ara ararauna) nesting in the urban area of Rondonópolis, a Brazilian city located in Cerrado biome (a global biodiversity hotspot) feed on fruits from the exotic palm tree species Roystonea oleracea (pers. obs.). Similar to Phoenix canariensis, Roystonea specimens have great ornamental value. In the Brazilian setting, Roystonea are also strong indicators of economic status, and are consequently often found in the backyards of more affluent families. Biologists who ignore the ecology of cities, advocate for the elimination of these palm trees and other exotic trees. Such elimination, however, would not be just innocuous, it would likely suppress the food source of a macaw species that, although non-endangered, has been experiencing population decline (Angeoletto et al 2019c).
Finally, it is essential to highligh two statements by Spennemann about cities: he states that "in an ecosystem of reduced biodiversity, the number of plant-animal interactions are reduced as well." Actually, cities often harbor significant biodiversity; 125 bird species (approximately 15\% of Cerrado avifauna) have been identified in an urban park in Rondonópolis City, Brazil (Angeoletto, unpubl. data) - other taxa are also abundant in urban ecosystems (Negri et al., 2019). A study focused on investigating urban backyards' flora has found hundreds of plant species growing in them (Angeoletto et al., 2017). In addition, the support provided by urban backyards' flora to the fauna is certainly not negligible (Cubino et al., 2019).

Spennemann rightly states that "ornamental plants are subject to fashion trends. While flowers (bulbs or vines) and shrubs are easily replaced as fashion changes take place, trees tend to be maintained." This statement has major implications for urban planning, especially in tropical cities in the southern hemisphere. These cities are usually located in biodiversity hotspots (MacGregor-Fors \& Escobar-Ibañez, 2017). However, its tree cover is poorly distributed, and usually concentrated in neighborhoods whose residents are upper middle class (Duarte \& Leite, 2019).

Democratizing urban afforestation in tropical cities is therefore an urgent task, both to increase the quality of life of its residents and to strengthen the support of trees for biological diversity.

\section{Corresponding AUTHOR}

*fabio_angeoletto@yahoo.es

\section{ACKNOWLEDGMENTS}

We would like thank Hypatia of Alexandria, brilliant mathematician, astronomer and philosopher and Flora Essy Angeoletto: two extraordinary women and inexhaustible sources of inspiration.

\section{REFERENCE}

Andreatta, T. R., Backes, F. A. A. L., Bellé, R. A., Neuhaus, M., Girardi, L. B., Schwab, N. T., \& Brandão, B. S. (2011). Análise da arborização no contexto urbano de avenidas de Santa Maria, RS. Revista da Sociedade Brasileira de Arborização Urbana, 6(1), 36-50.

Angeoletto, F., Leandro, D. D. S., \& Fellowes, M. D. (2019a). The consequences of Brazil's lack of trans- 
port planning is written in the blood of sparrows. Urban Geography, 40(8), 1191-1197.

Angeoletto, F., Fellowes, M. D., Essi, L., Santos, J. W., Johann, J. M., da Silva Leandro, D., \& Mendonca, N. M. (2019b). Ecología urbana y planificación: una convergéncia ineludible. Revista Electrônica em Gestāo, Educaçāo e Tecnologia Ambiental, 23(1), 1-8.

Angeoletto, F., da Silva Leandro, D., \& Paludetto, N. A. (2019c). Ecologia Translacional: informações ambientais aplicadas ao Planejamento e Gestão de Rondonópolis, MT, Brasil. Terr@ Plural, 13(3), 461-469.

Angeoletto, F., Sanz, J.; Albertin, R.; Silva, F. (2017). The grass is always greener on the other side of the fence: the flora in urban backyards of different social classes. Ambiente \& Sociedade, 20(1), 1-20.

Cubino, J. P., Cavender-Bares, J., Hobbie, S. E., Pataki, D. E., Avolio, M. L., Darling, L. E., ... \& Steele, M. K. (2019). Drivers of plant species richness and phylogenetic composition in urban yards at the continental scale. Landscape ecology, 34(1), 63-77.

Davis, M. A., Chew, M. K., Hobbs, R. J., Lugo, A. E., Ewel, J. J., Vermeij, G. J., ... \& Thompson, K. (2011). Don't judge species on their origins. Nature, 474(7350), 153-154.

Duarte, T. E. P. N., \& Leite, L. B. (2020). Cidades médias no Cerrado brasileiro: desafios para a conservação da biodiversidade.Terr@Plural,14(1),1-7.

Duarte, T. E. P. N., Angeoletto, F., Santos, J. W. M. C., da Silva, F. F., Bohrer, J. F. C., \& Massad, L. (2018). Reflexões sobre arborização urbana: desafios a serem superados para o incremento da arborização urbana no Brasil. Revista em Agronegócio e Meio Ambiente, 11(1), 327-341.
Hernández, M., Morales, A., \& Saurí, D. (2014) Ornamental plants and the production of nature (s) in the Spanish real estate boom and bust: the case of Alicante. Urban Geography, 35(1), 71-85.

Iwaniec, D. M., Cook, E. M., Davidson, M. J., Berbés-Blázquez, M., Georgescu, M., Krayenhoff, E. S., ... \& Grimm, N. B. (2020). The co-production of sustainable future scenarios. Landscape and Urban Planning, 197, 103744.

MacGregor-Fors, I., \& Escobar-Ibáñez, J. F. (Eds.). (2017). Avian ecology in Latin American cityscapes. Springer.

Negri, I. C. O., Negri, S. S., \& Angeoletto, F. (2019). As cidades médias brasileiras precisam ser mais amigáveis aos morcegos, principalmente nos hotspots de biodiversidade.Terr@ Plural, 13(3),446-460.

Rumble, H., Angeoletto, F., Connop, S., Goddard, M. A., $\&$ Nash, C. (2019). Understanding and applying ecological principles in cities. In Planning Cities with Nature (pp. 217-234). Springer, Cham.

Spennemann, D. H. (2019a). The contribution of the Canary Island date palm (Phoenix canariensis) to the winter diet of frugivores in novel ecosystems. European Journal of Ecology, 5(1), 27-37.

Spennemann, D. H. (2019b). The connective potential of vertebrate vectors responsible for the dispersal of the Canary Island date palm (Phoenix canariensis). Flora, 151468.

Spennemann, D. H. (2019). The contribution of the Canary Island date palm.

Spennemann, D. (2018). Observations on the consumption and dispersal of Phoenix canariensis drupes by the Grey-headed flying-fox (Pteropus poliocephalus). European Journal of Ecology, 4(1), 41-49. 